Available online at GSC Online Press Directory

GSC Biological and Pharmaceutical Sciences

e-ISSN: 2581-3250, CODEN (USA): GBPSC2

\title{
Ethnobotany of "Pandap": Traditional cuisine from Saibatin community in West Pesisir Regency, Lampung, Indonesia
}

\author{
Wakhidah Anisatu Z. ${ }^{1,}{ }^{*}$ and Silalahi Marina ${ }^{2}$ \\ 1 Postgraduated Plant Biology Program, Graduated School, Bogor Agricultural University, Bogor \\ 2 Departement of Biology Education, Faculty of Education and Teacher Training, Universitas Kristen Indonesia, Jakarta.
}

Publication history: Received on 06 November 2019; revised on 20 November 2019; accepted on 24 November 2019

Article DOI: https://doi.org/10.30574/gscbps.2019.9.2.0210

\begin{abstract}
Pandap is traditional food owned by lampung saibatin community made from a mixture of grated coconut (Cocos nucifera) and various typical lampung spices coated with taro leaves (Colocasia esculenta) then wrapped in banana leaves (Musa sp.) and boiled. There has been no ethnobotanical research regarding this unique lampung food. The purpose of this study is to explain how many species of plants used in cooking pandap, plants utilization patterns, and how it is processed so it can be consumed. Secondly, to describe the nutritional content and secondary metabolite in used plants. And the last, to report the various uses of pandap by saibatin community in West Pefsisir Regency and the source of used plants acquisition. Data collection was conducted using interview questionnaires and participant observation methods. The results showed that there were 16 species of plants belonging to 11 families used in pandap cooking process. The plants are divided into 4 utilization patterns, there are main ingredients, spices, fragrances, and wrappers. Each plant has nutrients, such as fat content, fiber, proteins, mineral, and various secondary metabolite content that enriches the taste of pandap. The lampung saibatin community uses pandap as a dish during weddings, customary title ceremony, and also daily food sold on the traditional market. The largest source of used plants in cooking pandap comes from the homegarden, which is 69\% (11 species).
\end{abstract}

Keywords: Ethnobotany; Lampung saibatin; Traditional food; Pandap; West Pesisir

\section{Introduction}

It has became Indonesia's superiority when talking about traditional cuisine diversity. Indonesia is pluralistic nation consisting of thousands tribes, it is not surprising that the traditional cuisines from various ethnic groups in Indonesia become so rich. For example, the traditional foods which come from Batak tribe are very diverse and differ to another. Here, a special food owned by Batak Toba tribe called Naniura fish which made from uncooked fish processed by only fermented acid and then seasoned. The dishes are usually served during marriage, funeral, welcoming new house, and childbirth [1]. There is also Riau tribe's traditional food from named Anyang Pucuk Botiek and Anyang Paik Pangkuk Pangkek made from mixture stew vegetable and coconut milk which is also served during traditional events [2].

Saibatin lampung tribe is one of indigenous community in Indonesia that still holds their customs rules strongly. This community resides in along mountainous and coastal area of Lampung Province, such as Krui, Ranau, Komering, to Kayu Agung [3]. The saibatin lampung community has a special food called pandap, it's similar to Javanese food named bothok. Main ingredient used by both is grated coconut (Cocos nucifera) mixed with various spices. The difference, pandap is wrapped first with taro leaves and then boiled, but bothok is only wrapped in banana leaves and then steamed [4].

The ethnobotany studies on pandap has not yet been implemented so far, though this food is very well known in Pesisir Barat region. As time goes by, not many people know a detailed recipes in making this traditional food. It would be unfortunate if none documentation and study about this authentic food from Pesisir Barat community. Therefore, a

\footnotetext{
* Corresponding author

E-mail address:khistia.nisa@gmail.com
} 
research is needed to explain used ingredients, nutritional content, how to make it, cultural use of pandap, and sources of plant acquisition which used in pandap. The purposes of this study are, first to explain plants pecies used in pandap, its utilization patterns and how to process till can be consumed. Second, to describe the nutritional content and active substances in used plants based on previous research studies. Third, to describe cultural use of pandap by lampung saibatin community in West Persisir Regency and sources of used plant acquisition.

\section{Material and methods}

\subsection{Study area}

This research was conducted in two villages (pekon), Labuhan Mandi and Way Jambu, in West Persisir Regency, Lampung Province during October - November 2018 (Figure 1). Both villages have very different geographical landscapes, Labuhan Mandi is located at highland and directly adjacent to South Bukit Barisan National Park (TNBBS), meanwhile Way Jambu is located in coastal area directly adjacent to the Indian Ocean. Even though the both separated in different geographical area, they have same kind traditional food called pandap, which its ingredients and cooking process are similar.

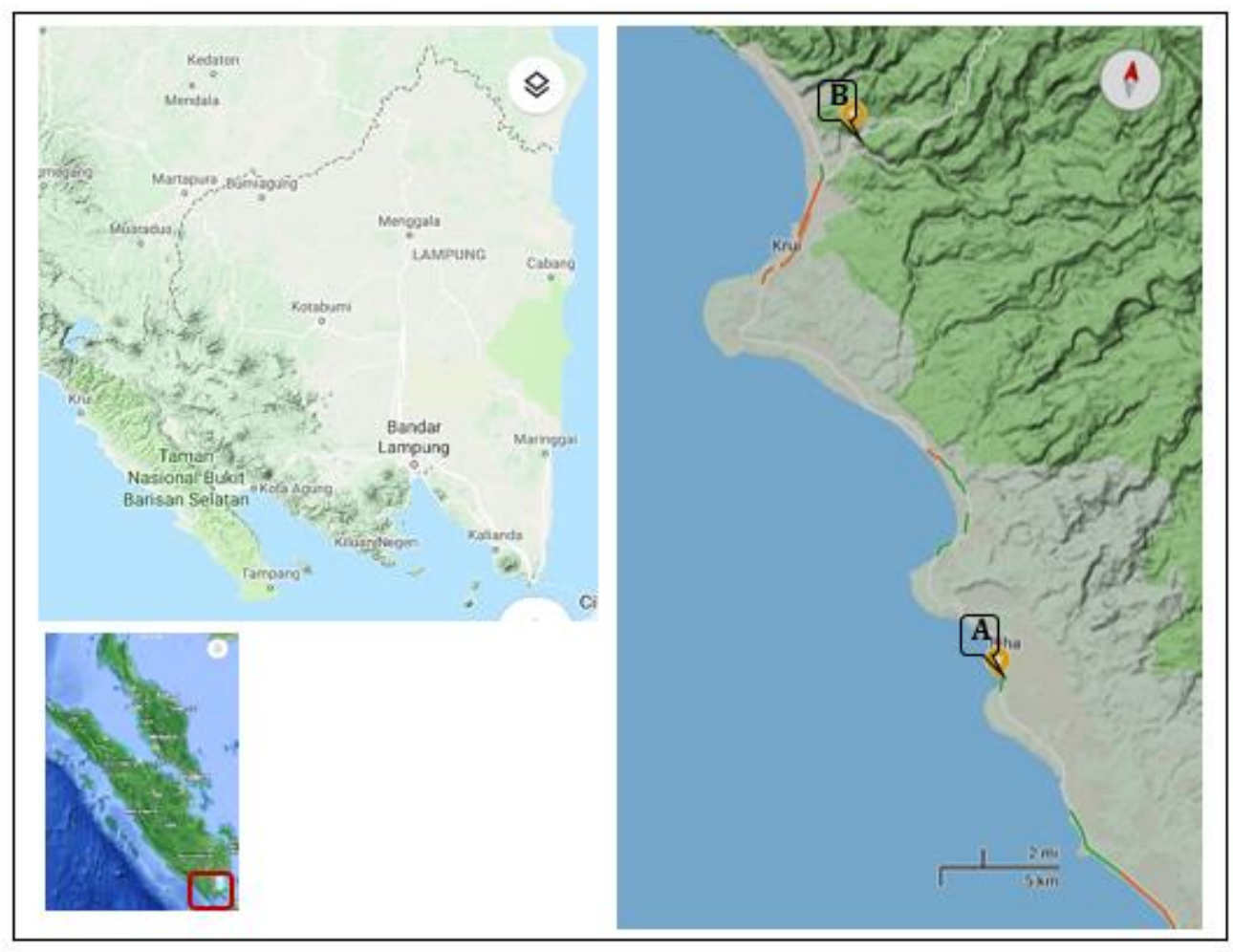

Figure 1 Data collection site for study ethnobotany of pandap: traditional food owned by saibatin community at West Persisir Regency, Lampung Province; Way Jambu Village (A) dan Labuhan Mandi Village (B). Source: Google Maps 2019

Labuhan Mandi village is included to Way Krui Subdistrict, while Way Jambu village belongs to Pesisir Barat Subdistrict. The distance from Labuhan Mandi village to capital district, Krui, is $6 \mathrm{~km}$. While the distance from Way Jambu village to Krui is further about $35 \mathrm{~km}$. The majority of residents' livelihoods in both villages are farmers, farming in fields or farming in policulture garden. There are differences in plant commodities between Labuhan Mandi and Way Jambu. Labuhan Mandi community gardens are polyculture gardens which usually called repong. That garden type contains variety plant species, such as damar (Shorea javanica) and annual fruit plants. Whereas Way Jambu community gardens is biculture garden dominated by only coconut (Cocos nucifera) and melinjo (Gnetum gnemon). This brief description is enough to show the landscape difference between two villages (Figure 2). 

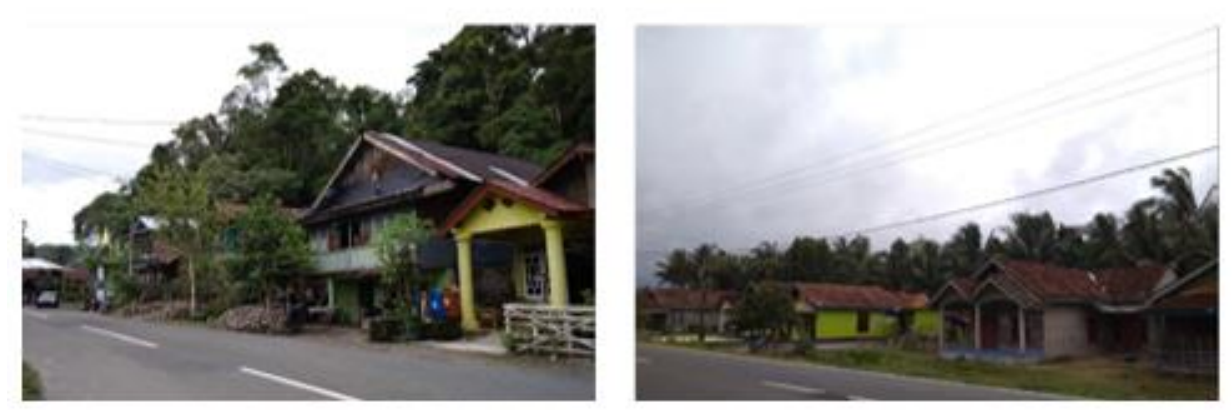

Figure 2 The appearance of Labuhan Mandi Village which is surrounded by fruits plants (left); Way Jambu village's area which is dominated by coconut trees (right). Source: Personal Documentation

\subsection{Data collection and analysis}

Data were collected using interview questionnaire method [5] and participant observation [6]. Respondents consisted of 35 general respondents in each village [7] and key respondents, that is pandap maker and seller found at Labuhan Mandi and Way Jambu. Collected data is the form of used plant species in making pandap, parts of used plants, source of its acquisition, how to make pandap, efficacy of used plants, and culture use of pandap by local people at both villages. Data were analyzed using descriptive qualitative approach, presented using tables, then compared with another literature which discuss similar matter originating from various Indonesia regions.

\section{Results and discussion}

\subsection{Used plants species in cooking Pandap}

Based on the results reported as many as 16 plants species belonging to 11 families are used in cooking pandap. Zingiberaceae is the most widely used plant family ( 4 species), followed by Amaryllidaceae and Arecaceae which contains 2 plant species. The other plant families is only composed of 1 species (Table 1). The most widely used part is fruit ( 8 species), followed by rhizomes ( 4 species), leaves ( 3 species), and stems ( 1 species). Every plant species has a specific used pattern in cooking pandap. There are 4 pattern, as main ingredient, spices, fragrance, and wrapping.

Plant species from Zingiberaceae and Amallidaceae have function as spice to create special pandap flavor, they are, Cucurma longa, Alpinia galanga, Kaempferia galanga, Zingiber officinale (Zingiberaceae), Allium cepa, and Allium sativum (Amaryllidaceae). Those plants have been very popularly used as spice in many regions of Indonesia [8; 9; 10; 11;2]. Even though the way of utilization is different among region, in example utilization Alpinia galanga in Javanese cuisine is enough by crushed its rhizome and then put in or sauteed with the dish [12]. While the way use by saibatin lampung community is finely mashed with other herbs then mixture together, called bumbu lampung.
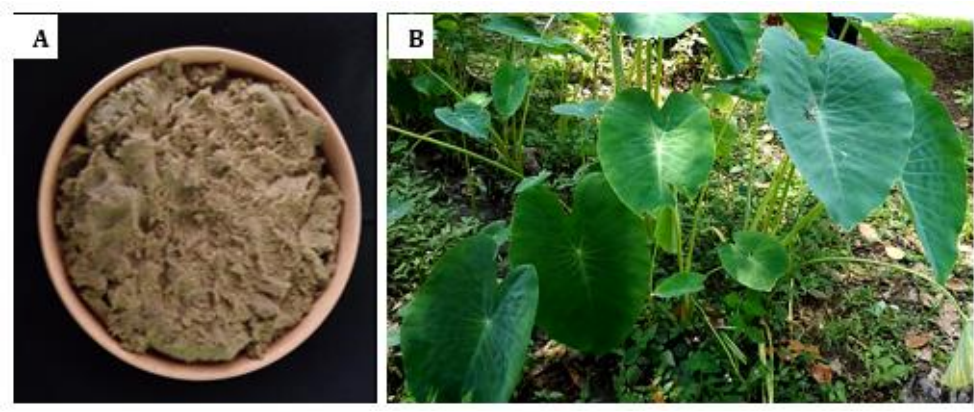

Figure 3 Grated coconut that has been mixed with various Lampung spices (3A) and then wrapped using young bebat leaves (Colocasia esculenta) (3B), then boiled \pm 8 hours until the cooking water runs out. Source: Personal documentation

The other plants used for seasoning, namely Coriandrum sativum (Apiaceae), Aleurites moluccanus (Ephorbiaceae), and Capsicum frutescens (Solanaceae). Those plants are also mashed and mixed with grated and roasted coconut (Cocos nucifera) (Figure 3A). The dough of grated coconut and spices are taken as much as 3--5 spoons, then wrapped using bebat leaves (Colocasia esculenta). The number of wrapping leaf is as many as 7 strands for young leaves and 20 strands 
for younger leaves (Figure 3B). Utilization of bebat leaves is intended to compact the coconut dough and to keep it not broken during boiling process. In addition, bebat leaves are special unique of pandap, when it's done cooked it also eaten together with the dough. Similar dough is also found in Javanese cuisine called bothok. The difference is bothok not wrapped by bebat leaves but directly wrapped by banana leaves [4].

Tabel 1 Used plant species in cooking pandap by local community in West Pesisir Regency, Lampung, here also included local name, habitus, part of used, utilization pattern and acquisition source

\begin{tabular}{|c|c|c|c|c|c|}
\hline Latin Name & Local name & Habitus & Part of Used & $\begin{array}{l}\text { Utilization } \\
\text { Pattern }\end{array}$ & $\begin{array}{l}\text { Acquisition } \\
\text { Source }\end{array}$ \\
\hline \multicolumn{6}{|l|}{ Amaryllidaceae } \\
\hline Allium сера & Bawang merah & herb & tuber & spice & market \\
\hline Allium sativum & Bawang putih & herb & tuber & spice & market \\
\hline \multicolumn{6}{|l|}{ Apiaceae } \\
\hline Coriandrum sativum & Ketumbar & herb & tuber & spice & market \\
\hline \multicolumn{6}{|l|}{ Araceae } \\
\hline Colocasia esculenta & Talas bebat & herb & leaves & $\begin{array}{l}\text { main } \\
\text { ingredient }\end{array}$ & homegarden \\
\hline \multicolumn{6}{|l|}{ Arecaceae } \\
\hline Areca catechu & Pinang & tree & fruit & fragrance & homegarden \\
\hline Cocos nucifera & Kelapa & tree & fruit & $\begin{array}{l}\text { main } \\
\text { ingredient }\end{array}$ & homegarden \\
\hline \multicolumn{6}{|l|}{ Clusiaceae } \\
\hline Garcinia xanthochymus & Asam kandis & tree & fruit & fragrance & market \\
\hline \multicolumn{6}{|l|}{ Euphorbiaceae } \\
\hline Aleurites moluccana & Kemiri & tree & fruit & spice & market \\
\hline \multicolumn{6}{|l|}{ Musaceae } \\
\hline Musa sp. & Pisang & herb & leaves & pembungkus & homegarden \\
\hline \multicolumn{6}{|l|}{ Myrtaceae } \\
\hline Syzygium polyanthum & Daun salam & tree & leaves & fragrance & homegarden \\
\hline \multicolumn{6}{|l|}{ Poaceae } \\
\hline Cymbopogon citratus & Serai & herb & stem & spice & homegarden \\
\hline \multicolumn{6}{|l|}{ Solanaceae } \\
\hline Capsicum frutescens & Cabe burung & shurbs & fruit & spice & homegarden \\
\hline \multicolumn{6}{|l|}{ Zingiberaceae } \\
\hline Cucurma longa & Kunyikh & herb & rhizome & spice & homegarden \\
\hline Alpinia galanga & Lawas & herb & rhizome & spice & homegarden \\
\hline Kaempferia galanga & Cekur & herb & rhizome & spice & homegarden \\
\hline Zingiber officinale & Jahi & herb & rhizome & spice & homegarden \\
\hline
\end{tabular}

After wrapped by bebat leaves, pandap is wrapped using banana leaves (Musa sp.). For wrapper, local people in Pesisir Barat prefer use banana leaves from cultivar ambon (Musa acuminata cv. Ambon). This is probably due to the scent which produced by Musa acuminata cv. Ambon's leaves more fragrant and gives more pleasant taste to pandap compared to other cultivar banana leaves. The content of flavor compounds in ambon banana leaves is more abundant (7 compounds) compared to other banana leaf which used in that study [13]. 

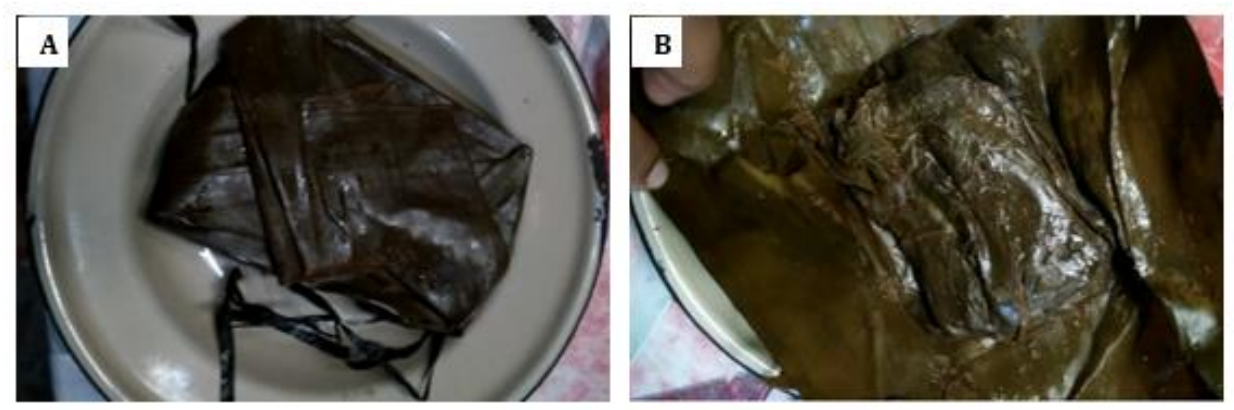

Figure 4 Pandap is wraped using banan leaves, rectangular in shape and tried to prevent the dough broken during the cooking process (4A); Inside the Pandap after opened and ready to be served (4B). Source: Personal documentation

After wrapped using banana leaves (Musa sp.), Pandap is boiled mixed with kandis acid (Garcinia xanthochymus), bay leaf (Syzygium polyanthum), turmeric (Cucurma longa), pinang (Areca catechu), salt, and various spices that have been mashed before. Addition of those various plants is intended as a fragrance during boiling process. It takes \pm 8 hours, until it is fully cooked and ready to be served (Figure 4 A \& B). Pandap cooking process requires longer time compared to bothok which is only \pm 30 minutes [4]. That is because pandap is coated with bebat leaves (Colocasia esculenta) in layers, the long boiling time aims to ripen the leaves of the bebat. Beside it that treat helps the cooking spice more pervasive so that the pandap taste more delicious. When tasted, pandap's taste was salty mixed with a strong flavor of spice, while its aroma was combination from banana leaves and various seasoning stew during the cooking process.

\subsection{Nutrition in pandap}

There are 4 plants used patterns in cooking pandap namely, plants as main ingredients, spices, fragrances, and wrappers (Table 1). Those plant which used as the main ingredient are, grated coconut (Cocos nucifera) and bebat leaves (Colocasia esculenta). Based on the analysis of nutritional content, roasted grated coconut contains quite high fat which is $18.29 \mathrm{~g}$ per serving as much as 1 ounce. That amount is the highest among other nutritional content in grated coconut. Besides fat, 1 ounce of grated coconut also contains protein (1.95 g), carbohydrate (6.7 g), sodium (10 mg), and potassium (154 mg) (Table 2). Thus the calories contained in pandap are quite high, considering the fat content of the main ingredients is also quite high.

Table 2 Nutrition information contained in roasted grated coconut with serving size as much as 1 ounce [14]

\begin{tabular}{lr}
\hline Serving size & 1 ounce roasted granted coconut \\
\hline Calories & $187 \mathrm{kcal}$ \\
Fat & $18,29 \mathrm{~g}$ \\
$\quad$ Saturated fat & $16,221 \mathrm{~g}$ \\
$\quad$ Polyunsaturated fat & $0,2 \mathrm{~g}$ \\
$\quad$ Monounsaturated fat & $0,778 \mathrm{~g}$ \\
$\quad$ Cholesterol & $0 \mathrm{mg}$ \\
Protein & $1,95 \mathrm{~g}$ \\
Carbohydrate & $6,7 \mathrm{~g}$ \\
$\quad$ Fiber & $4,6 \mathrm{~g}$ \\
Sugar & $2,08 \mathrm{~g}$ \\
Sodium & $10 \mathrm{mg}$ \\
Potassium & $154 \mathrm{mg}$ \\
\hline
\end{tabular}

Colocasia esculenta leaves contain more medicinal properties [15], for instance the contents of effective mucus for tranquilizers. The leaf also acts as a stimulant, expectorant thinner, appetizer enhancer, tissue contracting agent to reduce the secretion glands in the skin (astringent) to maintain skin moisture. The content of other substances include, minerals (calcium oxalate, calcium phosphorus), fiber, starch, flavonoids, anthocyanins and vitamins A, B, C. The anthocyanin content in bebat leaves serves to protect the skin and stimulates hair growth [15]. Other uses of bebat leaves are used as a wound medicine by people of West Kalimantan [16]. Several studies have shown that the leaf has an active compound that acts as an antibacterial and anti-inflammatory [17]. 
There are 10 species have been used as spice of pandap, that most belonging to Zingiberaceae (4 species). Those spices are also often used in many regions in Indonesia, such as coriander (Coriandrum sativum) used by Osing community, Banyuwangi for spices regional cuisine [8]. Coriander contains essential oils which can be a stimulus to strengthen digestive organs and increase appetite [18]. Candlenut (Aleurites moluccana) have been used by the people of Empoto Village, West Kalimantan as spices [19]. Candlenut seed has potential as antitumor, it seed contains the saponins, flavonoids, polyphenols, tannins, and fatty oils [19]. The cayenne pepper (Capsicum frutescens) becomes important spice in many Indonesian dishes as well as for typical Saibatin Lampung cuisine. It's proved by many Indonesian people, especially Lampung Saibatin community, like the spicy taste produced from capsaicin in chili. Cayenne pepper contains more vitamin than other species of chili [8], which is good for eye health and cure sore throat [20].

There are 3 species that are used as fragrances in the process of cooking pandap. These three plants, namely areca nut (Areca catechu), kandis acid (Garcinia xanthochymus), and bay leaf (Syzygium polyanthum). The Areca catechu seed gives a sense of bitter when chewed due to its sap content. The content of substances in areca nuts, such as phenols and tannins, has antifungal effects [21] specifically inhibiting the growth of fungi of the Candida spp. and antibacterial [22]. The flesh of kandis acid (Garcinia xanthochymus) contains organic acids such as hydroxy citric acid which can inhibit the formation of fat in the body [23] so that the potential for weight loss. Meanwhile, bay leaf (Syzygium polyanthum) is widely used as a flavoring because it produces a fragrant aroma when mixed in cooking [24]. The fragrance is produced from the essential oil content composed of citral compounds, eugenol, tannins and flavonoids. These compounds are thought to reduce excess blood sugar levels so that it has the potential as a diabetes drug [25].

Banana leaves (Musa sp.) are wrapper that is well known throughout Indonesia. A thick cuticle layer on the surface of its leaf, allows the leaf to accommodate various types of food to thick soupy food. It also gives a natural taste and special aroma to the food. Before used to wrap, the banana leaves are roasted or dried in the sun first by the users. The goal purpose is to make the banana leaf stronger and more elastic when used for wrapping [26]. The distinctive taste and fragrance of banana leaf comes from the content of flavor compounds commonly found on banana leaves. These flavor compounds such as 2-Methoxy-4-vinylphenol, Phytol, 1,2-Benzenedicarboxylic acid, bis (2-ethylhexyl) ester, Vanillin, and E-15-Heptadecenal. Of the six compounds that play an important role in producing taste and aroma are vanillin compounds [13].

\subsection{Utilization of pandap by saibatin community}

It is well known that pandap is a unique food of Lampung Saibatin community in West Pesisir region, precisely in Way Jambu and Labuhan Mandi Village. The community consumes pandap as daily food. Thus, the business of cooking and selling pandap at market is one of sources of income for Saibatin community at West Pesisir Regency. Many pandap sellers can be found in Friday or Sunday market at Labuhan Mandi Village (Figure 5). While in Way Jambu Village, pandap sellers usually go around the village to peddle this special foods. In addition, the pandap is also a typical dish during marriage feast, and granting ceremony of traditional title for Saibatin community. Usually the owner of event will order pandap from cookers (tradional food businessman) who are well known in each village in West Pesisir.

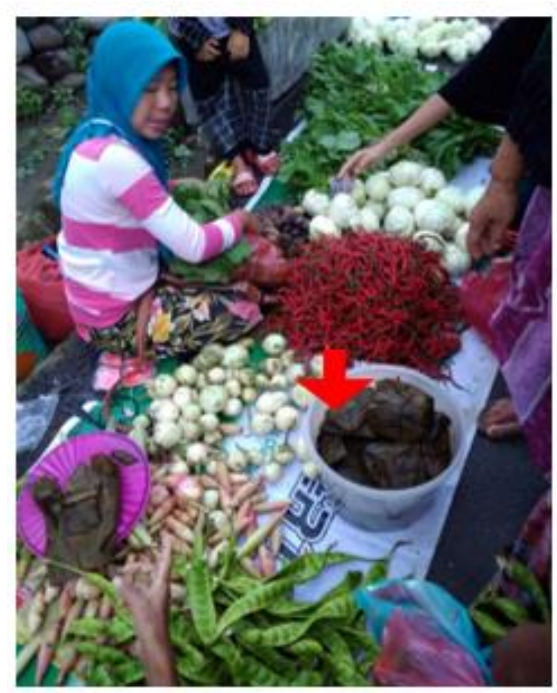

Figure 5 Pandap is also sold in the market as daily food (given an arrow indicating pandap). Source: Personal documentation 
Most of plant acquisition sources used in cooking of pandap are from the residents' homegarden, 11 of 16 plant species (Table 1). The people of Labuhan Mandi and Way Jambu Village are quite good in managing their yard to fulfill their daily food needs. Besides that, since the markets at villages in West Pesisir are not open every day, communities plant food crops and spices at their homegarden to support their daily food needs. Plants used as spices such as Capsicum frutescens, Cucurma longa, Alpinia galanga, Kaempferia galanga, and Zingiber officinale are almost always found in residents' yards. Likewise, the main ingredient plants for cooking pandap namely bebat (Colocasia esculenta) and coconut (Cocos nucifera) are easily found in the yard of local community.

A total 4 species used in cooking pandap are obtained from the market, two of them are onion (Allium cepa) and garlic (Allium sativum). Communities in both village rarely plant both plant species. This was suspected due to the geographical condition of West Pesisir region. Since these both regions conditon more supportive the growth of coconut, resin, and fruit plants, thus not many residents grow the vegetable crops. Moreover, the supply of vegetables including shallots and garlic has been fulfilled by villages' plantations in West Lampung Regency, which is a hugest vegetable supplier in Lampung. Therefore, the West Pesisir people prefer to buy shallots and garlic rather than planting them in the yard.

\section{Conclusion}

Based on research has been done it showed, there are as many as 16 plant species used in cooking pandap. Plants from Zingiberaceae family are most widely used they are 4 species. There are 4 utilization patterns of plants in cooking pandap, as the main ingredients, spices, fragrances, and wrappers. Each plant as pandap raw material for has good nutrition for the body, such as coconut which contains high fat and taro leaves that contain lots of fiber. As a daily food, pandap is also consumed as a special dish on the wedding feat and on the granting ceremony of traditional title. Sources of plants acquisition that are used in cooking pandap mostly come from homegarden of West Pesisir community, as many as 69\% (11 species).

\section{Compliance with ethical standards}

\section{Acknowledgments}

This article would never have existed without assistance from the saibatin community in West Pesisir Regency, especially the Way Jambu Village and Labuhan Mandi Village who were willing to share their knowledge with the author. And also thank you for advice from the supervisor.

\section{Disclosure of conflict of interest}

The authors declare no conflict of interest.

\section{References}

[1] Hasairin A. (2014). Variasi, keunikan dan ragam makanan adat etnis batak toba suatu kajian prospek etnobotani. Jurnal Pengabdian Kepada Masyarakat, 20, 21-26.

[2] Tribudiarti M, Syamsuardi, Nurainas. (2018). Studi etnobotani jenis rempah yang digunakan dalam bumbu masakan tradisional adat di Kerajaan Rokan Kabupaten Rokan Hulu, Riau. Jurnal Ilmu-Ilmu Hayati - Berita Biologi, 17(2), 175-182.

[3] Putri YY, Gunawan A, Arifin NHS. (2013). Kajian lanskap pemukiman tradisional masyarakat lampung saibatin di Pekon Kenali, Lampung Barat, Jurnal Permukiman 8(3), 153-167.

[4] Jalil M. (2019). Keanekaragaman dan asas manfaat keluarga zingiberaceae di Dusun Jambean Kabupaten Grobogan. Life Science, 8(1), 64-74.

[5] Martin GJ. (1995). Ethnobotany - a methods manual, Chapman \& Hall, Kew, UK, 108-111.

[6] Gómez-Beloz A. (2002). Plants use knowledge of the Winikina Warao: The case for questionnaires in ethnobotany. Economy Botany. 56, 231-241.

[7] Hoffman B, Gallaher T. (2007). Importance indices in ethnobotany. Ethnobotany Research \& Application, 5, 201218.

[8] Hakim L, Batoro J, Sukenti K. (2015). Etnobotani rempah-rempah di Dusun Kopen Dukuh, Kabupaten Banyuwangi. Jurnal Pembangunan dan Alam Lestari, 6(2), 133-142. 
[9] Iskandar J, Iskandar BS. (2015). Studi etnobotani keanekaragaman tanaman pangan pada "Sistem Huma" dalam menunjang keamanan pangan Orang Baduy. Prosiding Seminar Nasional Masyarakat Biodiversitas Indonesia, 1265-1272.

[10] Rahayu M, Prawiroatmodjo S. (2005). Keanekaragaman tanaman pekarangan dan pemanfaatannya di Desa Lampeapi , Pulau Wawoni - Sulawesi Tenggara. Jurnal Teknologi Lingkungan BPPT, 6(2), 360-364.

[11] Robi Y, Kartikawati SM, Muflihati. (2019). Etnobotani rempah tradisional di Desa Empoto Kabupaten Sanggau Kalimantan Barat. Jurnal Hutan lestari, 7(1), 130-142.

[12] Apriliani A, Sukarsa S, Hidayah HA. (2016). Kajian etnobotani tumbuhan sebagai bahan tambahan pangan secara tradisional oleh masyarakat di Kecamatan Pekuncen Kabupaten Banyumas. Scr. Biol. 1(1), 78.

[13] Mastuti TS, Handayani R. (2014). Senyawa kimia penyusun ekstrak ethyl asetat dari daun pisang batu dan ambon hasil distilasi air. Prosiding SNST Fakultas Teknik UNWAHAS, 1(1), 60-64.

[14] Fatsecret Indonesia. (2019). Kandungan gizi kelapa parut 1 ons. Available at https://fatsecret.co.id/kalorigizi/umum/kelapa-kering, Accessed on Monday, 6 May 2019, 14:08 WIB.

[15] Prajapati R, Kalariya M, Umbarkar R, Parmar S, Sheth N. (2011). Colocasia esculenta: A potent indigenous plant. International Journal Nutrition, Pharmacology, Neurological Diseases, 1(2), 90--96.

[16] Khairany N, Idiawati N, Wibowo MA. (2015). Analisis sifat fisik dan kimia gel ekstrak etanol daun talas (Colocasia esculenta (L.) Schott). Jurnal Kimia Khatulistiwa, 4(2), 81-88.

[17] Biren NS, BS Nayak, SP Bhatt, SS Jalalpure, AK Seth. (2007). The anti-inflamantory of the leaves of Colocasia esculenta. Saudi Pharmaceutical Journal, 15, 228-232.

[18] Duke JA, Bogenschutz-Godwin MJ, Du Ceillier JD, Duke P. (2002). Handbook of medial spices. CRC Press

[19] Sembiring BS, Winarti C, Baringbing B. (2003). Identifikasi komponen kimia minyak daun salam (Eugenia polyantha) dari Sukabumi dan Bogor. Buletin Peneliti Tanaman Rempah Dan Obat, 14(2), 9-16.

[20] Yuwono, SS. (2015). Cabai Rawit (Capsicum frutescens L.) Available at http://darsatop.lecture.ub.ac.id/2015/10/cabai-rawit-capsicum-frutescens-l/. Accesed on Friday, 14 June 2019 15.10 WIB.

[21] Putriningrum R, Khoiriyah A. (2014). Kajian efek sinergistik anti jmur esktrak biji pinang (Arecacathechu L.) dan daun sirih merah (Piper betle L.) untuk pencegahan kandididasis vulvovaginal. Jurnal Kesehatan Kusuma Husada, $5(1), 42-49$.

[22] Nursidika P, Saptarini O, Rafiqua N. (2014). Aktivitas antimikrob fraksi ekstrak etanol buah pinang (Areca catechu L) pada bakteri Methicillin Resistant Staphylococcus aureus. Majalah Kedokteran Bandung, 46(2), 94-99.

[23] Jena BS, Jayaprakasha GK, Sakariah KK. (2002). Organic acid from leaves, fruits and rinds of garcinia cowa. Journal Agricultural Food Chemistry. 50, 3431-3434.

[24] Romadhon, AF. (2014). Kemiri (Aleurites moluccana). Available at https://ccrc.farmasi.ugm.ac.id/?page_id=121, Accessed on Wednesday, 15 May 2019, 13.00 WIB.

[25] Studiawan H, Santosa MH. (2005). Uji aktivitas penurun k adar glukosa darah ekstrak daun Eugenia polyantha pada mencit yang diinduksi aloksan. Media Kedokteran Hewan, 21(2), 62-65.

[26] Rini R, Fakhrurrozi Y, Akbarini D. (2018). pemanfaatan daun sebagai pembungkus makanan tradisional oleh masyarakat Bangka (studi kasus di Kecamatan Merawang). Ekotonia Jurnal Penelitian Biologi Botani Zoologi Dan Mikrobiologi, 2(1), 20-32.

\section{How to cite this article}

Wakhidah AZ. \& Silalahi M. (2019). Ethnobotany of "Pandap": Traditional cuisine from Saibatin community in West Pesisir Regency, Lampung, Indonesia. GSC Biological and Pharmaceutical Sciences, 9(2), 126-133. 